\title{
The Extent of Higher Education Institutions Commitment in Serving Community According to Its Social Responsibility
}

\author{
Ismail Salameh Iriqat ${ }^{1}$ \\ ${ }^{1}$ Department of Public Administration, Birzeit Universiy, Palestine \\ Correspondence: Ismail Salameh Iriqat. E-mail: ismaeel_ar@yahoo.com
}

Received: October 25, 2019

Accepted: November 5, 2019

Online Published: November 19, 2019

doi:10.5539/ass.v15n12p100

URL: https://doi.org/10.5539/ass.v15n12p100

\begin{abstract}
The purpose of the study is to investigate the extent of higher education institutions commitment in serving community according to its social responsibility. Accordingly; the researcher adopted the descriptive analytical approach through using the quantitative approach by developing a questionnaire fitting the nature of the study. Based on this the study concluded several findings; indicating that the evaluations of faculty members for the role of Palestinian higher education institutions participated in the study (Beir Zait. Al-najah. American University) are in an average level in the domains of encouraging faculty members on participating in conferences as well as local and international seminars. Developing courses and academic programs and directing scientific research to solve community problems. Additionally, serving special needs people in the community. Meanwhile, the evaluations of faculty members for the role of Palestinian higher education institutions participated in the study were high in the domains of preserving environment, seeking to serve the community and social responsibility towards its employees.

Based on the findings the study reached several recommendations such as; the need to work to establish social responsibility in the curricula and university courses specializing in community service and bring about desired behavioral changes. And put social responsibility at the heart of the general strategies of institutions of higher education so as to have a key role in establishing a competitive strategic thought that serves society and its issues by addressing its problems and seeking solutions to them using scientific methods. Enhancing coordination between higher education institutions and research centers in holding seminars and conferences and participating in the preparation of studies and researches related to community issues.
\end{abstract}

Keywords: higher education institutions, serving community, social responsibility, academic programs, scientific research, preserving environment, special needs people

\section{Introduction}

Since a short period of time the concept of social responsibility occurred within the trends to encounter poverty and unemployment. As we all activating the role of special need people and including them in their communities. This concept was absent in the past since most of the responsibility was held by the government, however, the development of education imposes new responsibilities on educational institutions to practice their social responsibility (Shaheen, 2011).

Bakker (2011) argued that universities are social organizations designed through its jobs and tasks to serve the community. Therefore, those universities must obtain certain roles by identifying the societal needs of individuals, groups and institutions, and designing activities and programs that meet these needs through its various colleges and research centers in order to bring about desirable developmental and behavioral changes. It aims to enable community members, institutions and bodies to achieve the maximum possible benefit from the various services provided by the University in a variety of ways and methods commensurate with the circumstances of the beneficiary and actual needs.

It is worth to mention, that universities are required - more than any other time- to take into account all procedures and activities to obtain social responsibility in the light of its goals and vision (Dhayaffi, 2010). According to this context, the role of higher education is dealing with society issues, spreading cultural awareness though listing social responsibility in its strategic plans; as well as all designing and carrying out activities fulfilling the needs of the community and serve the mission of higher education in general (Bermen, 
1990). Therefore, the purpose of the study is to investigate the extent of higher education institutions commitment in serving community according to its social responsibility.

\section{Research Problem and Questions}

The conference of social responsibility of higher education institutions held in Nablus in 2011 confirmed the need to increase the role of higher education institutions in the field of social responsibility, insuring quality of education as well as scientific research to cope with the development of the local community. Further, indicating the need to make a plan for the social responsibility as a main component of the declared strategic plan of higher education institutions. Therefore, the current research is conducted (9) years later in order to explore the development and the trends of adopting social responsibility by higher education institutions as a mean for leading and serving the Palestinian community. Specifically, the current study is seeking to answer the following main question: What is the extent of higher education institutions in serving community according to its social responsibility? The sub-questions are:

1. To what extent do higher education institutions encourage faculty members to participate in local and international scientific conferences and seminars to promote social responsibility?

2. To what extent do institutions of higher education contribute to the development of academic courses and programs to meet the needs of society to promote social responsibility?

3. To what extent do the institutions of higher education contribute scientific research to study and solve the problems of society in promoting social responsibility?

4. To what extent do institutions of higher education contribute to the service of society with special needs to promote social responsibility?

5. To what extent do institutions of higher education contribute to the interest and preservation of the environment to promote social responsibility?

\section{Research Objectives}

1. Exploring the commitment of higher education institutions of social responsibility towards the community.

2. Presenting the features of social responsibility regarding the role of social responsibility in motivating the community.

3. Concentrating on the employees' attention of social responsibility domains in those institutions.

4. Providing practical initiatives in dealing with social responsibility in higher education institutions.

5. Evaluating the social role of higher education institutions through the measurement of social responsibility elements,

\section{Significance of Research}

1. Determining the domains of social responsibility valid to be applied in higher education institutions.

2. Revealing the status of applying and adopting social responsibility in higher education institutions.

3. Empowering the basic concepts of social responsibility and educating higher education institutions about those concepts since they are very important in developing the community.

4. Evaluating the social role of higher education institutions by measuring the elements of social responsibility.

5. Providing findings and recommendations to enrich the Palestinian experiment in the field of social responsibility.

\section{Study Hypotheses}

1. Higher education institutions encourage faculty members to participate in local and international scientific conferences and seminars to promote social responsibility in a high degree.

2. Higher education institutions contribute to the development of academic courses and programs to meet the needs of society to promote social responsibility in a low degree.

3. Higher education institutions contribute scientific research to study and solve the problems of society in promoting social responsibility in a low degree.

4. Higher education institutions contribute to the service of society with special needs to promote social responsibility in an average degree.

5. Institutions of higher education contribute to the interest and preservation of the environment to promote 
social responsibility in a low degree.

\section{Study Variables}

Independent variable: higher education institutions commitment. Including:

- Participate in local and international scientific conferences

- Developing courses and academic programs.

- Scientific research.

- $\quad$ Serving special needs people.

- Preserving and keeping environment.

Dependent variable: serving community according to social responsibility.

\section{Literature Review}

\subsection{Literature Review}

\section{Definition of University social Responsibility}

The University social responsibility is a policy of ethics concerning performance in higher education institutions as well as the social duties of university within teaching, scientific research and community services (Vallaryes, Dela Cruz, \& Sasia, 2009).

Furthermore, it is the policy of ethical quality performance of the university community namely; students, faculty as well as administrative staff in carrying out all the social duties of the university within teaching, research and community.

For Vasilescua, Barnab, Epurec \& Baicud (2010: 4178) its "about the need to strengthen civic commitment and active citizenship; it is about volunteering, about an ethical approach, developing a sense of civil citizenship by encouraging the students, the academic staff to provide social services to their local community or to promote ecological, environmental commitment for local and global sustainable development".

\section{Areas of University social Responsibility}

University social responsibility has different areas; those areas are summarized as by Alzyoud \& Bani-Hani (2015) as follows:

1. The need to strengthen civil commitment and active citizenship.

2. To provide services to the community through community engagement and outreach.

3. To promote economic and national development.

4. To promote ethical approaches to issues.

5. To develop a sense of civil citizenship by encouraging the students and the academic and administrative staff to provide social services to their local community.

Moreover, other areas include; according to (Monge et al., 2019) the following:

1. To promote ecological or environmental commitment for local and global sustainable development.

2. To develop local and global human resources.

3. To expand human knowledge through quality research and education for the nation and for humanity.

\section{Role of University in practicing social Responsibility}

Universities can practice University social responsibility (USR) through promoting the protection of community health, safety, and the environment. Practicing USR refers to support of issues that are important to the public but that are within the limits and resources of the university. Examples of such issues include improving education in the community, pursuing environmental excellence, practicing resource conservation, promoting and improving the health of the community, performing community service, conducting research to generate socio-economic development, and providing guidelines for the development and sustainability of society ( Chen, Nasongkhla, \& Donaldson, 2015).

Furthermore, USR contains the university role in issues like social, environmental and economic; those should not be separated from a university's strategic planning and operation, which is an important aspect of how universities interact with their internal and external stakeholders, and the society. Studies showed clear consensus that a social dimension should integrate both policy and strategic planning in higher education 
institutions. In addition, the dimension of networking, accountability, and ethics should also be integrated as guiding principles for the role of universities in society (Dima, Vasilache, Chinea, \& Agoston, 2013).

Monge et al. (2019) summarized the role of universities in achieving social responsibility as follows:

1. Incorporating social and civic competences in vocational training.

2. Opening its facilities for community activities purposes.

3. Designing Social development programs through its academic programs.

4. Employing scientific research and teaching in the social, economic and environmental development.

Giffre \& Ratto (2014: 234) argued that higher education institutions can practice social responsibility through disseminate and implement a set of general principles and specific values, using four key processes: Management, Teaching, Research and Extension, through the provision of educational services and transfer knowledge following ethical principles, good governance, respect for the environment, social engagement and the promotion of values". Social engagement of HEI has become one of the fundamental pillars of universities. Hence, social service is considered as a core mission, that equal to teaching and research.

In this sense Bermen (1990: 77) stated that the role of higher education institutions in social responsibility is represented in:

1. Developing an understanding of global education, multicultural education and system analysis.

2. Exploring world issues: this can be done through inquiry, critical thinking, dialogue and negotiation.

3. Training individuals to be responsible members of their communities: this can be done through setting shared goals, practicing decision making as well as promoting vocational training.

4. Social and economic development plans and strategic action plans.

\subsection{Previous Studies}

Heello (2013) studied the role of the Palestinian universities in serving the local society in light of its social responsibility from the view point of their teaching staff where Al-Aqsa University has been taken as a case study. In order to achieve, the objectives of the study the researcher adopted the analytical descriptive approach. The study concludes the following results: The role of the university in serving society in light of their social responsibilities from the view point of the members of the teaching staff does not reach more than $60 \%$. The researcher has also found out that there are statistical significant relationship at the significance between the role of the university in the serving society and responsibility towards the employees and the students. The researcher has also found out that there are no statistical differences about the role of the university in serving society in light of their social responsibilities are attributed to personal variables like (gender, age, years of service and place of work). The researcher has recommended the need to enhance the relationship between the university and the local society and the university should put all its facilities in serving the local society.

Nasereldin, Shiqwara \& Al-hila (2013) concluded that Jordanian private universities took careful attention to serve the community through conferences, seminars and workshop regarding different aspects of social sides; as well as providing services for special needs people. Moreover, preserving the environment through cleaning campaigns, and protecting historical places. However, there is a shortage in survey studies about the needs of the community and how to fulfill those needs.

In another study Shaheen (2011) concluded that the university is carrying out a special role in the field of social responsibility represented in the establishment of a unit to take care of graduate students and communicating with the society to find training opportunities and employment for them. Further, the university is offering schoolships, qualifying women, visiting prisoners and injured people as well as helping farmers. The study recommended a set of recommendations, most notably: Institutionalizing social responsibility through its inclusion in the university plan, objectives, procedures, aspects of evaluating its performance and putting social responsibility at the center of its strategies to identify the needs of society continuously.

Sabah (2014) concluded that the university is suffering from the contradiction between the content of the higher education and the demands of the labor market. The abilities and skills needed in the labor market especially technological ones are not provided by the university, since most of the students study humanitarian majors. Because of this the labor market refuses those outcomes since human resources need training and qualifying. There is a shortage in the coordination between the university and the society organizations on all levels therefore, the university is unable to fulfill the needs of the society. Further, there is an importance aspect that universities must develop human resources which in turn will work to develop the society. 
Jaber and Mahdi (2011) concluded that the work of Al-Azhar University administration is limited to the tactical work imposed by the circumstances because there is no clear plan on social responsibility, while the strategic plan of Helwan University includes elements to strengthen the relationship with the local community. To study the needs of the labor market and the suitability of specializations with them, the two universities lack the existence of the needs study center, but Helwan University has a unit of relations management in each college, the two universities hold exhibitions and cultural, development and training seminars that serve With, trying both universities to develop new disciplines keep pace with scientific developments and meet the needs of the community.

\section{Research Methodology}

\subsection{Study Design}

The study adopted the descriptive analytical approach which is based on studying the phenomenon as it is in the reality, then expressing that in both qualitative and quantitative approaches. This approach analyses and explains data in order to reach conclusions to form a suggested proposal and provide recommendations.

\subsection{Sample of the Study}

Since there is a difficulty in surveying all higher education institutions in Palestine, the researcher adopted the available sample by choosing three universities; those are: Beirzeit University, Al-najah University and the American University. The questionnaire was distributed on 300 members in those universities and retrieved all of them. Table (1) shows the final numbers of the sample according to gender, years of experience and academic rank.

Table 1. Distribution of the sample according to gender, years of experience and academic rank variables

\begin{tabular}{cccc}
\hline Variable & & No & $\%$ \\
\hline \multirow{3}{*}{ University } & Beirzeit university & 100 & 33.3 \\
& Al-najah University & 100 & 33.3 \\
& The American University & 100 & 33.3 \\
\hline
\end{tabular}

\subsection{Study Tool}

To achieve the aim of the study related to the extent of higher education institutions commitment in serving community according to its social responsibility as perceived by faculty member in Palestinian higher education institutions, the researcher developed a questionnaire within 28 items.

\subsection{Tool Validity and Reliability}

Content Validity: The tool will be submitted to a panel of staff members from the Faculty of Educational Sciences in Universities. The jury members were asked to judge the instruments and determine if it is suitable for the purpose of the study. They were asked to add, delete, or modify any of the test questions.

Cronbach's Alpha was used to check reliability. Table (2) shows that the reliability coefficient is (0.916) showing a high rate of reliability, and therefore, the questionnaire is valid to be administrated.

Table 2. Reliability coefficient of the tool

\begin{tabular}{ccc}
\hline Domain & Items & Cronbach's Alpha \\
\hline Total degree & 28 & 0.916 \\
\hline
\end{tabular}

For the purposes of the study the researcher calculated the faculty members evaluations for the role of universities according to their social responsibility as follows:

Table 3. Item Weighs

\begin{tabular}{cc}
\hline Means & Degree \\
\hline to Less or equal 2.33 & Low \\
From 2.34 to less or equal 3.67 & Average \\
Fro, 3.68 to less or equal 5 & High \\
\hline
\end{tabular}

\section{Results}

The results of the first question: To what extent do higher education institutions encourage faculty members to participate in local and international scientific conferences and seminars to promote social responsibility? 
To answer this question the following hypotheses was addressed (Higher education institutions contributes in encouraging faculty members in participating in conferences, and local as well as international seminars to promote social responsibility in a high degree).

To answer this question means and standard deviations were calculated to the arrangement of faculty members' evaluations for the role of Palestinian universities in encourage them to participate in local and international scientific conferences and seminars to promote social responsibility.

Table 4. Means, Standard deviations and arrangement for faculty members' evaluations for the role of Palestinian universities in encourage them to participate in local and international scientific conferences and seminars to promote social responsibility

\begin{tabular}{|c|c|c|c|c|c|}
\hline No & Item & M & SD & Arra & Degree \\
\hline 4 & $\begin{array}{l}\text { High education institutions host experts and specialists in social responsibility to } \\
\text { enrich conferences organized by faculty members }\end{array}$ & 4.27 & 0.58 & 1 & high \\
\hline 5 & $\begin{array}{l}\text { Higher education institutions provide media coverage for epical conferences of social } \\
\text { responsibility and publish faculty members productivity }\end{array}$ & 4.15 & 1.32 & 2 & Average \\
\hline 1 & $\begin{array}{l}\text { High education institutions oblige its members to organize conferences of social } \\
\text { responsibility }\end{array}$ & 3.51 & 1.32 & 3 & average \\
\hline 2 & $\begin{array}{l}\text { High education institutions give leaves for faculty members to participate in local and } \\
\text { international conferences }\end{array}$ & 3.27 & 1.27 & 4 & average \\
\hline \multirow[t]{2}{*}{3} & $\begin{array}{l}\text { High education institutions encourage professor participation in international } \\
\text { conferences of social responsibility through paying expanses }\end{array}$ & 3.15 & 1.36 & 5 & average \\
\hline & $\begin{array}{l}\text { The role of higher education institutions in encouraging participation in local and } \\
\text { international scientific conferences and seminars }\end{array}$ & 3.67 & 0.74 & & average \\
\hline
\end{tabular}

Table 4 shows that the faculty members' evaluations for the role of Palestinian universities in encourage them to participate in local and international scientific conferences and seminars to promote social responsibility was in an average level, as the total mean of their responses was 3.67 with a standard deviation of 0.74 . With regard to the items expressing the role of higher education institutions in encouraging its faculty members to participate in conferences and seminars; the means ranged between 4.27 in its higher range and 3.15 in its lowest range. The highest was (High education institutions host experts and specialists in social responsibility to enrich conferences organized by faculty members) with a mean of 4.27 and standard deviation of 0.58 . While, the lowest was (High education institutions encourage professor participation in international conferences of social responsibility through paying expanses) with a mean of 3.15 and standard deviation of (1.36).

The results of the second question: To what extent do institutions of higher education contribute to the development of academic courses and programs to meet the needs of society to promote social responsibility?

For this question the hypothesis was: higher education institutions contribute to the development of academic courses and programs to meet the needs of society to promote social responsibility in a low degree.

To answer this question means and standard deviations as well as arrangements of faculty members' evaluations for the role of institutions of higher education in the development of academic courses and programs to meet the needs of society to promote social responsibility were calculated as shown in table (5)

Table 5. Means and standard deviations as well as arrangements of faculty members' evaluations for the role of institutions of higher education in the development of academic courses and programs to meet the needs of society to promote social responsibility

\begin{tabular}{clcccc}
\hline No & \multicolumn{1}{c}{ Item } & M & SD & Arra & Degree \\
\hline 3 & Higher education institutions have academic programs for community services & 3.97 & 0.81 & 1 & high \\
1 & There are special courses about the issues of the community & 3.55 & 1.34 & 2 & average \\
5 & Higher education institutions adopt modern courses for community services & 3.18 & 1.19 & 3 & average \\
4 & $\begin{array}{l}\text { Academic programs are designed to assist people to be creative and innovative and } \\
\text { discuss idea }\end{array}$ & 3.15 & 1.25 & 4 & average \\
2 & $\begin{array}{l}\text { Academic programs meets the needs of community labor market } \\
\text { Role of institutions of higher education in the development of academic courses and } \\
\text { programs to meet the needs of society to promote social responsibility }\end{array}$ & 3.36 & 0.88 & 5 & average \\
& & & average \\
\hline
\end{tabular}


Table 5 shows those faculty members' evaluations for the role of institutions of higher education in the development of academic courses and programs to meet the needs of society to promote social responsibility were in an average degree with a mean of 3.36 and standard deviation of 0.88 . The items means ranged between average and high degrees, as one item was high and other four items were in an average degree. The means ranged between 3.97 and 2.94 with a total average degree.

The highest item was (Higher education institutions have academic programs for community services) with a mean of 3.97 and standard deviation of 0.81 . While, the lowest was (Academic programs meets the needs of community labor market) with a mean of 2.94 and standard deviation of 1.34. The role of institutions of higher education in the development of academic courses and programs to meet the needs of society to promote social responsibility was in an average degree with a mean of 3.36 and standard deviation of 0.88 .

The results of the third question: To what extent do the institutions of higher education contribute scientific research to study and solve the problems of society in promoting social responsibility?

To answer this question the following hypothesis was addressed: Higher education institutions contribute in directing scientific research to study and solve the problems of the society to promote social responsibility in a low degree.

To answer this question means, standard deviation and arrangement of faculty members evaluations for the role Higher education institutions in directing scientific research to study and solve the problems of the society to promote social responsibility were calculated as shown in table (6)

Table 6. Faculty members' evaluations for the role Higher education institutions in directing scientific research to study and solve the problems of the society to promote social responsibility

\begin{tabular}{|c|c|c|c|c|c|}
\hline No & Item & $\mathrm{M}$ & SD & Arra & Degree \\
\hline 6 & $\begin{array}{l}\text { Higher education institutions encourage faculty members and students to participate } \\
\text { in scientific research contests related to social responsibility on both local and } \\
\text { international levels }\end{array}$ & 4.00 & 0.91 & 1 & high \\
\hline 5 & The university budget contains items related to the studies of social responsibility & 3.83 & 0.70 & 2 & high \\
\hline 1 & Faculty members see research as a means for promotion ant serving society & 3.36 & 1.37 & 3 & average \\
\hline 2 & $\begin{array}{l}\text { Higher education institutions publish the studies of faculty members and students } \\
\text { for the society }\end{array}$ & 3.25 & 1.25 & 4 & average \\
\hline \multirow[t]{2}{*}{4} & $\begin{array}{l}\text { There is coordination between the university and research centers to make } \\
\text { cooperative programs to carry out society studies. }\end{array}$ & 3.19 & 1.23 & 5 & average \\
\hline & $\begin{array}{l}\text { Role Higher education institutions in directing scientific research to study and solve } \\
\text { the problems of the society to promote social responsibility }\end{array}$ & 3.45 & 0.73 & & average \\
\hline
\end{tabular}

Table 6 shows that the evaluations of faculty members were in an average level with a mean of 3,45 and standard deviation of 0.73 . With regard to items evaluations ranged between high and average, as two items were high and other three were in an average level, the means were 4.00 in its highest range and 3.19 in its lowest range.

The highest item was (Higher education institutions encourage faculty members and students to participate in scientific research contests related to social responsibility on both local and international levels) with a mean of 4.00 and standard deviation of 0.91. While, the lowest was (There is coordination between the university and research centers to make cooperative programs to carry out society studies) with a mean of 3.19 and standard deviation of 1.23 .

Findings of the fourth question: To what extent do institutions of higher education contribute to the service of society with special needs to promote social responsibility?

To address this question the study dealt with the following hypothesis: higher education institutions contribute in serving special needs people to promote social responsibility.

To answer this question means and standard deviations and arrangements were calculated for the role of higher education institutions in serving special needs people, as shown in table (7)

Table 7. Means and standard deviations and arrangements were calculated for the role of higher education institutions in serving special needs people

\begin{tabular}{clcccc}
\hline No & Item & M & SD & Arra & Degree \\
\hline 1 & Higher education institutions provide special needs people with grants and funding & 3.75 & 0.90 & 1 & High \\
3 & The library of higher education institutions includes a special equipment, section & 3.71 & 1.01 & 2 & High \\
\hline
\end{tabular}


and equipment for people with special needs

2 There are special facilities such as parks and WC

$3.70 \quad 1.21 \quad 3 \quad$ High

Higher education institutions provide volunteers to accompany and help special needs students.

Higher education institutions provide the requirements of the educational process to suit their needs such as the provision of course books in Braille.

Higher education institutions organize extracurricular and voluntary activities and initiatives for people with special needs.

Role of higher education institutions in serving special needs people

$\begin{array}{llll}3.62 & 0.90 & 4 & \text { Average } \\ 3.33 & 0.73 & 5 & \text { Average } \\ 3.00 & 0.24 & 6 & \text { Average } \\ 3,52 & 0.71 & & \text { Average }\end{array}$

Table 7 shows that the evaluations of faculty members for the role of higher education institutions in serving special need people came in an average level with a mean of 3.52 and standard deviation of 0.73 . With regard to items related to this role; the means ranged between high and average as three items were high and other three were in an average level. The means ranged between 3.75 in its highest range and 3.00 in its lowest range.

The highest was (Higher education institutions provide special needs people with grants and funding) with a mean of 3.75 and 0.90 standard deviation. Meanwhile, the lowest was (Higher education institutions organize extracurricular and voluntary activities and initiatives for people with special needs) with a mean of 3.00 and standard deviation of 0.24 .

Findings of the fifth question: To what extent do institutions of higher education contribute to the interest and preservation of the environment to promote social responsibility?

This question addressed the following hypothesis: Higher education institutions contribute in preserving environment to promote social responsibility in a low degree.

To answer this question means and standard deviations and arraignment were calculated for the evaluations of faculty members to the role of higher education institutions in preserving environment to promote social responsibility

Table 8. Means and standard deviations and arraignment were calculated for the evaluations of faculty members to the role of higher education institutions in preserving environment to promote social responsibility

\begin{tabular}{clcccc}
\hline No & \multicolumn{1}{c}{ Item } & M & SD & Arra & Degree \\
\hline 4 & Higher education institutions take careful attention to green areas & 4.17 & 0.76 & 1 & high \\
2 & $\begin{array}{l}\text { Higher education institutions use alternative energy sources such as solar cells. } \\
3\end{array}$ & 3.99 & 0.83 & 2 & High \\
Higher education institutions have a waste water refining and reuse system. & 3.73 & 0.93 & 3 & Average \\
5 & $\begin{array}{l}\text { Higher education institutions coordinate with environmental protection } \\
\text { associations and competent authorities to launch initiatives on environmental } \\
\text { events such as Earth Day. }\end{array}$ & 3.59 & 0.73 & 4 & Average \\
& $\begin{array}{l}\text { The keenness of higher education institutions on the existence of graduation } \\
\text { projects dealing with environmental issues and finding solutions to address } \\
\text { environmental pollution. }\end{array}$ & 3.42 & 1.17 & 5 & Average \\
& $\begin{array}{l}\text { Higher education institutions hold seminars and conferences on environmental } \\
\text { pollution, its causes and risk. } \\
\text { Role of higher education institutions in preserving environment to promote social } \\
\text { responsibility }\end{array}$ & 3.35 & 1.22 & 6 \\
\end{tabular}

Table 8 shows that the evaluations of faculty members came to a high degree, where the average of their estimates was 3.71 and a standard deviation of 0.53 . The estimates of faculty members ranged from high to medium, with three paragraphs with a high score, three paragraphs with a medium score, and the arithmetic averages of the paragraphs ranged from 4.17 in the highest range to 3.35 in the lower range.

The highest items that indicate a high degree of roles played by institutions of higher education concern for the environment and conservation, are: "The University's concern for the existence of wooded areas" with an average of 4.17 and a standard deviation of 0.76 , while the lowest paragraphs that indicate an average degree of roles The institutions of higher education concern for the environment and preserve them are: "The university holds seminars and conferences on environmental pollution and its causes and risks" with an average of 3.35 and a standard deviation of 1.22 .

Findings of the sixth question: Are there any significant statistical differences between the responses of faculty members in Palestinian higher education institutions regarding the role of Palestinian higher 


\section{education institutions in serving the community and its social responsibility towards employees?}

This question addresses the following hypothesis: there are no significant statistical differences between the responses of faculty members in Palestinian higher education institutions regarding the role of Palestinian higher education institutions in serving the community and its social responsibility towards employees.

To answer this question Wallis Kruskal test was used to determine the differences, as shown in Table 9.

Table 9. Wallis Kruskal test results to determine differences between the responses of faculty members in Palestinian higher education institutions regarding the role of Palestinian higher education institutions in serving the community and its social responsibility towards employees, for academic rank. At freedom point $=2$.

\begin{tabular}{|c|c|c|c|c|c|}
\hline Domain & University & Ranks mean & test & Sig & Нур \\
\hline \multirow{3}{*}{$\begin{array}{l}\text { Encouraging participation in } \\
\text { conferences and seminars }\end{array}$} & Birzeit & 32.11 & & 0.000 & reject \\
\hline & American & 96.67 & 76.285 & & \\
\hline & An-najah & 97.72 & & & \\
\hline \multirow{3}{*}{$\begin{array}{l}\text { Developing curriculum and } \\
\text { academic courses }\end{array}$} & Birzeit & 30.45 & & 0.000 & reject \\
\hline & American & 104.37 & 83.646 & & \\
\hline & An-najah & 91.68 & & & \\
\hline \multirow{4}{*}{$\begin{array}{l}\text { Directing scientific research } \\
\text { to study and solve the } \\
\text { problems of society }\end{array}$} & Birzeit & 31.77 & & 0.000 & reject \\
\hline & American & 92.99 & 77.539 & & \\
\hline & An-najah & 101.74 & & & \\
\hline & Birzeit & 38.22 & & 0.000 & reject \\
\hline \multirow[t]{3}{*}{ Serving special needs people } & American & 75.20 & 75.179 & & \\
\hline & An-najah & 113.08 & & & \\
\hline & Birzeit & 48.63 & & 0.000 & reject \\
\hline \multirow[t]{3}{*}{ Preserving environment } & American & 85.58 & 29.606 & & \\
\hline & An-najah & 92.29 & & & \\
\hline & Birzeit & 31.20 & & 0.000 & reject \\
\hline \multirow[t]{2}{*}{ Total } & American & 94.33 & 78.734 & & \\
\hline & An-najah & 100.97 & & & \\
\hline
\end{tabular}

Table 9 shows that:

There are significant statistical differences at the level of 0.000 according to higher education institutions (beir ziat, American and Al-najah) regarding the role Palestinian higher education institutions regarding the role of Palestinian higher education institutions in serving the community and its social responsibility towards employees, as the highest means was for Al-najah University (100.97) as shown on Figure 1.

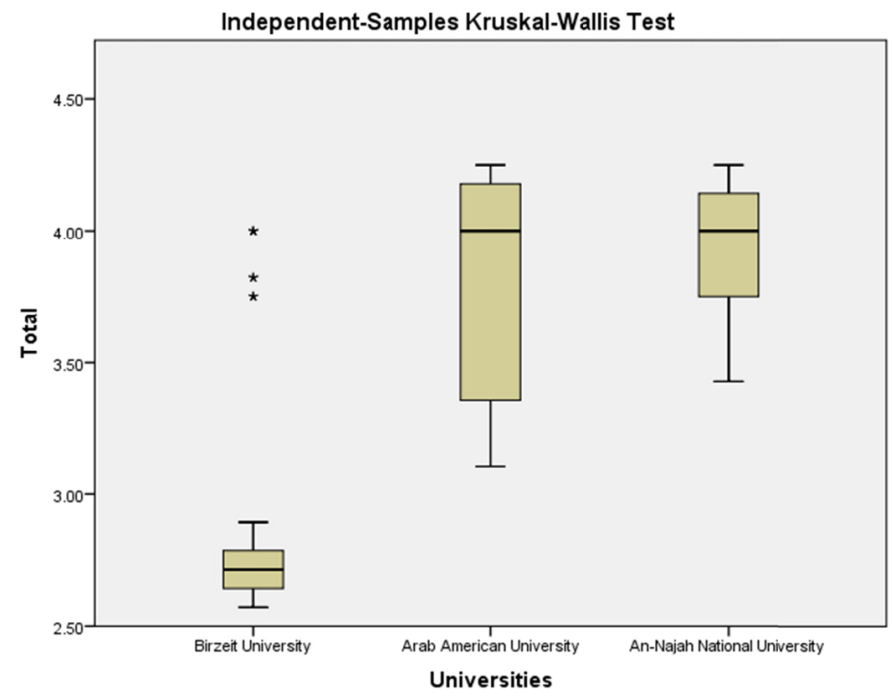

Figure 1. Wallis Kruskal test results to determine differences between the responses of faculty members in Palestinian higher education institutions regarding the role of Palestinian higher education institutions in serving the community and its social responsibility towards employees 
Moreover, there are significant statistical differences at the level of 0.000 in the role Palestinian higher education institutions regarding the role of Palestinian higher education institutions in serving the community and its social responsibility towards employees, as the highest means was for Al-najah University (97.92) as shown on Figure 2 .

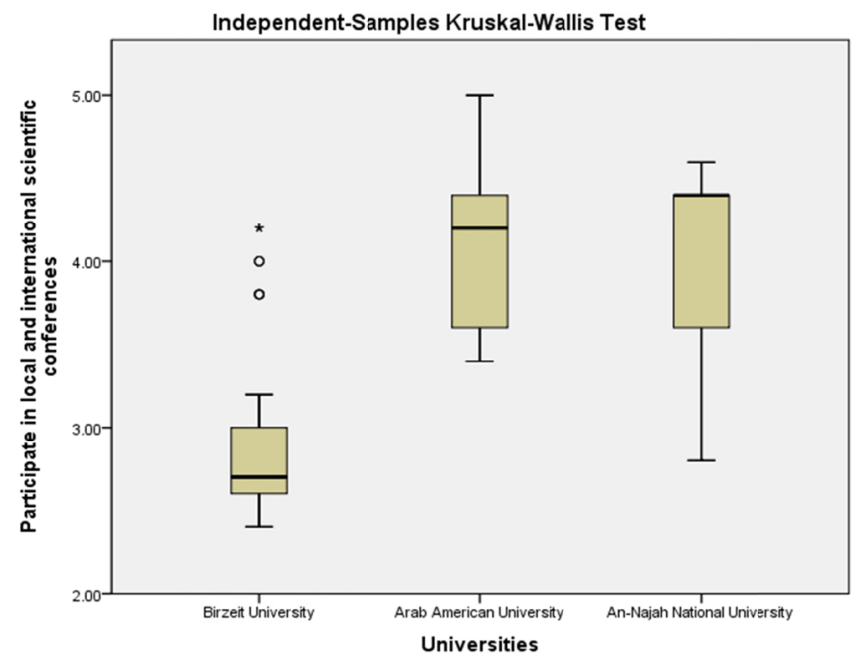

Figure 2. Wallis Kruskal test results to determine differences between the he role of Palestinian higher education institutions in encouraging participation in conferences and seminars

Moreover, there are significant statistical differences at the level of 0.000 in the role Palestinian higher education institutions regarding the role of Palestinian higher education institutions in developing curriculum and academic programs as the highest means was for American University (104.37) as shown on Figure 3.

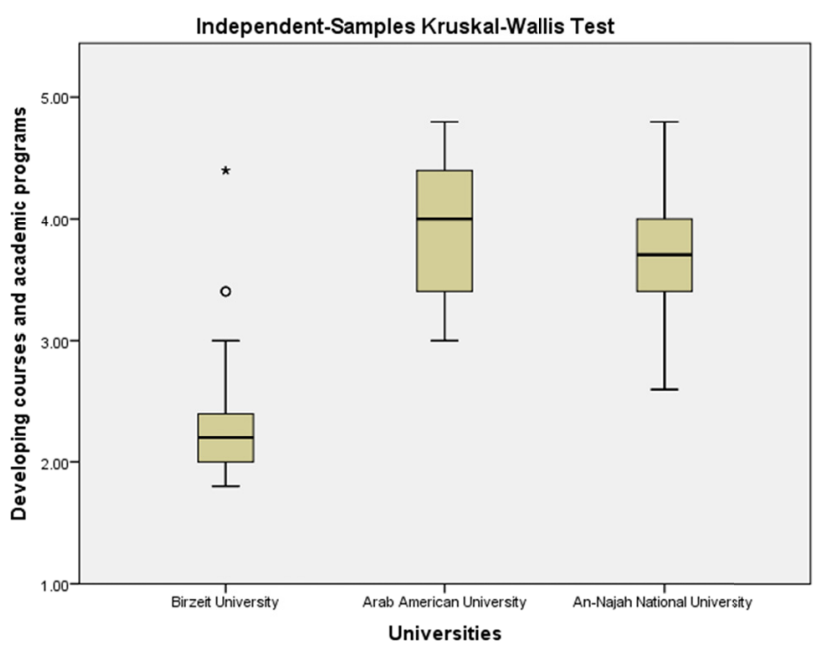

Figure 3. Wallis Kruskal test results to determine differences between the he role of Palestinian higher education institutions in curriculum and academic programs

There are significant statistical differences at the level of 0.000 in the role Palestinian higher education institutions regarding the role of Palestinian higher education institutions in directing scientific research in solving society problems and prompting social responsibility as the highest means was for Al-najah University (101.647) as shown on Figure 4.

There are significant statistical differences at the level of 0.000 in the role Palestinian higher education institutions regarding the role of Palestinian higher education institutions in serving special needs people as the highest means was for Al-najah University (113.08) as shown on Figure 5.

There are significant statistical differences at the level of 0.000 in the role Palestinian higher education institutions regarding the role of Palestinian higher education institutions in preserving environment as the highest means was for Al-najah University (92.29) as shown on Figure 6. 


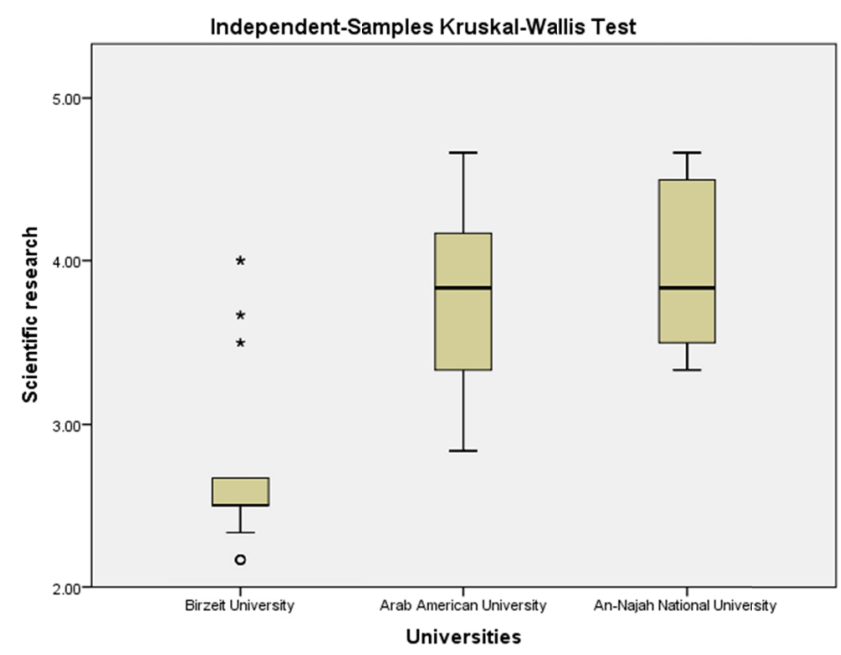

Figure 4. Wallis Kruskal test results to determine differences between the he role of Palestinian higher education institutions in directing scientific research in solving society problems and prompting social responsibility

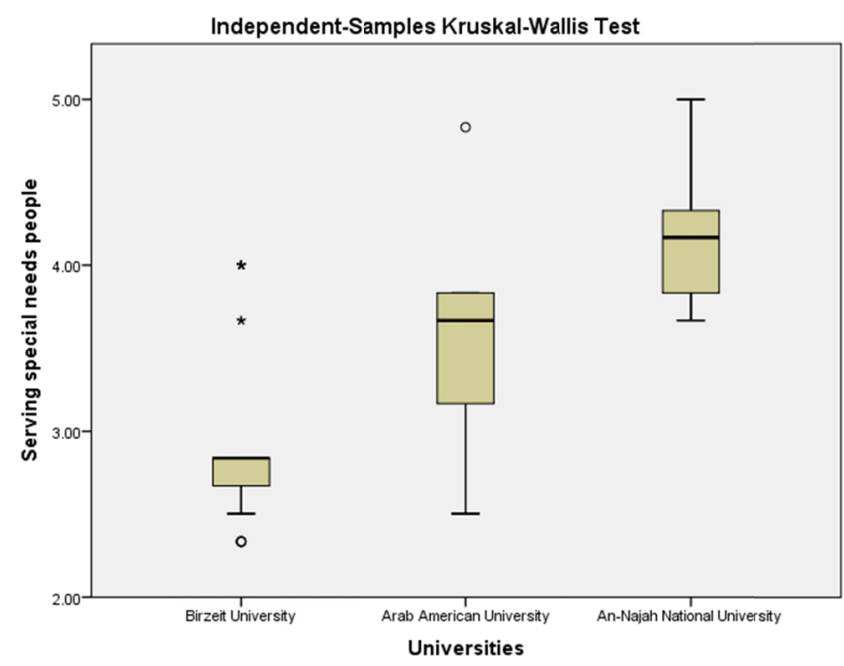

Figure 5. Wallis Kruskal test results to determine differences between the he role of Palestinian higher education institutions in serving special needs people

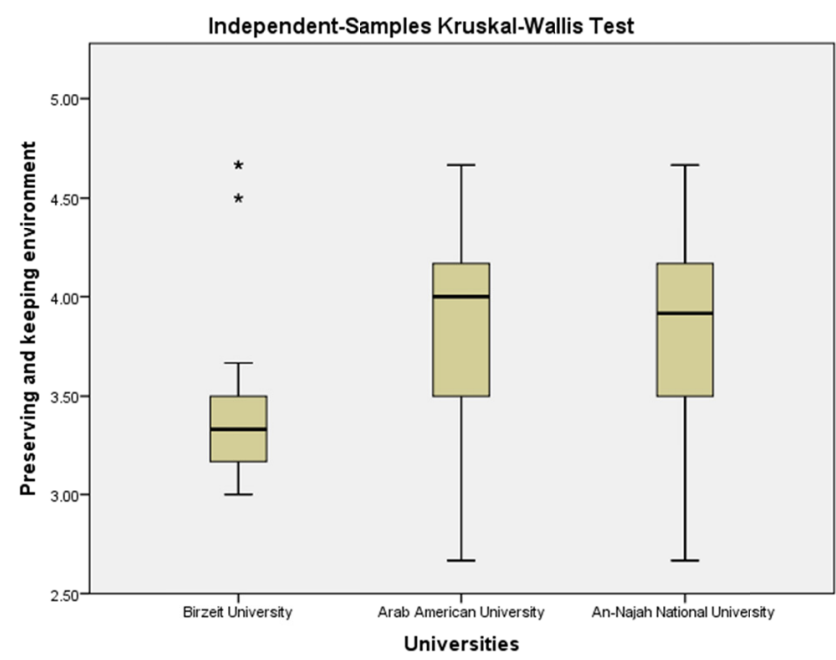

Figure 6. Wallis Kruskal test results to determine differences between the he role of Palestinian higher education institutions in preserving envirnment 
To determine the differences of the samples' responses regarding the role of higher education institutions in serving society and social responsibility towards employees pairwise comparisons were conducted as shown in Table 10

Table 10. Differences of the samples' responses regarding the role of higher education institutions in serving society and social responsibility towards employees according to pairwise comparisons test

\begin{tabular}{|c|c|c|c|}
\hline Domain & group1-group2 & Test value & Sig \\
\hline \multirow{3}{*}{$\begin{array}{l}\text { Encouraging participation in } \\
\text { conferences and seminars }\end{array}$} & Birzeit- American & -7.502 & 0.000 \\
\hline & American- Al-najah & -7.624 & 0.000 \\
\hline & American- An-najah & -.122 & 1.000 \\
\hline \multirow{3}{*}{$\begin{array}{l}\text { Developing curriculum and } \\
\text { academic courses }\end{array}$} & Birzeit- American & -7.084 & .000 \\
\hline & American- Al-najah & -8.552 & 0.000 \\
\hline & American- An-najah & 1.468 & .426 \\
\hline \multirow{3}{*}{$\begin{array}{l}\text { Directing scientific research to } \\
\text { study and solve the problems of } \\
\text { society }\end{array}$} & Birzeit- American & -7.070 & .000 \\
\hline & American- Al-najah & -8.081 & .000 \\
\hline & American- An-najah & -1.011 & .937 \\
\hline \multirow{4}{*}{ Serving special needs people } & Birzeit- American & -4.283 & .000 \\
\hline & American- Al-najah & -8.670 & 0.000 \\
\hline & American- An-najah & -4.387 & .000 \\
\hline & Birzeit- American & -4.276 & .000 \\
\hline \multirow[t]{2}{*}{ Preserving environment } & American- Al-najah & -5.052 & .000 \\
\hline & American- An-najah & -.776 & 1.000 \\
\hline \multirow{3}{*}{ Total } & Birzeit- American & -7.273 & .000 \\
\hline & American- Al-najah & -8.038 & .000 \\
\hline & American- An-najah & -.765 & 1.000 \\
\hline
\end{tabular}

Table 10 shows that:

There are significant statistical differences at the level of 0.000 in the respondents of the study sample at Birzeit University compared to the two American universities and the national success on the role of Palestinian higher education institutions in serving the society and their social responsibility towards their employees, while there are no 1 significantstatistica differences in the response of the study sample in Birzeit University. An-Najah and American Universities, since the average ranks of An-Najah and American Universities are higher than Birzeit University, the difference was in favor of the Al-Najah and American Universities in their role.

There are significant statistical differences at the level of 0.000 in the respondents of the study sample at Birzeit University compared to the American universities and Al-najah success on the role of Palestinian higher education institutions in encouraging participation in local and international scientific conferences and seminars to promote social responsibility, whereas there are no significant statistical differences in the response Members of the study sample at An-Najah and American Universities.

There are significant statistical differences at the level of 0.000 in the respondents of the study sample at Birzeit University compared to the American universities and Al-najah success on the role of Palestinian higher education institutions in directing scientific research to study and solve the problems of society to promote social responsibility, while there are no statistically significant differences in the response of the sample members Since the average grades of both Al-najah and American universities are higher than Birzeit University, the difference was in favor of Al-najah and American universities in directing scientific research to study and solve the problems of society to enhance Social Responsibility.

There are significant statistical differences at the level of 0.000 in the respondents of the study sample in the Palestinian higher education institutions participating in the study (Birzeit, Al-Najah, American) on the role of Palestinian higher education institutions in serving the special needs to promote social responsibility, whereas there are no differences. Statistical significance in the respondents of the study sample in An-Najah and American Universities, where the average grade of An-Najah National University (113.08) was higher than that of Birzeit and American Universities. 


\section{Conclusions}

The results indicated that the evaluations of the faculty members in the three universities were in an average level in the domains of encouraging faculty members to participate in conferences and seminars on both local and international levels as well as developing academic courses and programs. Further, directing scientific research to study and solve the problems of the community. Additionally, serving special needs people. Meanwhile, their evaluations were high in the domain of preserving and keeping environment and seeking to serve the community and social responsibility towards the employees.

Evaluations of faculty members also showed that there are statistically significant differences in the role of Palestinian higher education institutions in serving the community and their social responsibility towards their employees, where both Al-Najah National University and the American University have achieved the largest role in community service and social responsibility towards their employees compared to Birzeit University. An-Najah and American universities make a significant difference from Birzeit University in each of the domains of encouraging participation in local and international conferences and seminars, developing academic courses and programs, and directing scientific research to study and solve the community problems. Meanwhile, Al-najah University achieved the higher success in serving special needs people compared to the other two universities.

\section{Study Recommendations}

- Instilling social responsibility in courses and programs to serve community and making desirable changes.

- Finding academic programs in higher education institutions for community services to achieve balance and compatibility and mutual development between educational institutions and the community.

- Putting social responsibility in the heart of the general strategy of higher education to be effective in the competitive strategic thinking in the field of solving community problems.

- Enhancing coordination between high education institutions and scientific research centers in conducting conference and seminars as well as participating in studies and researches related to community.

- Promoting attitudes towards conducting specialized studies to make the desirable changes.

- Call on universities to carry out its social responsibility tasks by making students and effective members to carry out activities in that direction.

- Allocating special budgets to social responsibility to support it in practice and academically in the organization of seminars and conferences and encourage its academy to carry out studies and research aimed at serving the community.

- Increase Palestinian higher education institutions for training courses and awareness programs that give their employees towards social responsibility and importance.

- The need for specialized departments of social responsibility within the institutions of higher education to plan and implement programs and coordination with the relevant authorities, to follow the senior management directly, and exchange experience and practical experiences among them and identify the strengths and weaknesses to apply the best feasible methods in the areas of social responsibility.

\section{References}

Alzyoud, S., \& Bani-Hani, K. (2015). Social responsibility in higher education institutions: application case from the Middle East. European Scientific Journal, 11(8), 122-129.

Bakker, A. (2011). University Role Development in Serving community according to social Responsibility and International trends. Nablus: Al-Quds Open University.

Berman, S. (1990). Educating for Social Responsibility. Educational Leadership, 48(3), 75-80.

Chen, S., Nasongkhla, L., \& Donaldson, A. (2015). University Social Responsibility (USR): Identifying an Ethical Foundation within Higher Education Institutions. TOJET: The Turkish Online Journal of Educational Technology, 14(4), 165-173.

Dhayaffi, N. (2010). Social Responsibility for the Corporation and Human Resources (Unpublished Master thesis). Abu Baker Elqayed University. Algeria.

Dima, M., Vasilache, S., Ghinea, V., \& Agoston, S. (2013). A model of academic social responsibility. Review of Administrative Sciences, 1(1), 23-43.

Giffre, L., \& Ratto, S. (2014). A New Paradigm in Higher Education: University Social Responsibility (USR). 
Journal of Education \& Human Development, 3(1), 231-238.

Heello, E. (2013.). The Role of Higher education institutions in Palestiner in serving the Soceity as Perceived by faculty members (Master thesis). Islamic University. Gaza.

Jaber, M., \& Mahdi, N. (2011). The role of higher education institutions in promoting the concepts of social responsibility among students, a comparative field study. Helwan University and Al-Azhar University.

Monge, E., Audet, X., \& Martinez, J. (2019). Drivers and Barriers of University Social Responsibility: Integration into Strategic Planning. Annual Review of sociology, 1(10), 1-26.

Nasereldin, Y., Shiqwara, S., \& Al-hila, M. (2013). Jordanian special Universities social Responsibility as Perceived by local Leaders. Nablus: a;-Quds Open University.

Sabah, G. (2014). The Role of Higher Education in Community Development: An Analytical Study of Administrative Leadership Trends at Mohamed Khader University ( $\mathrm{PhD}$ Thesis). Mohamed Khedira University, Algeria.

Shaheen, M. (2011). Al-Quds Open University as A model: analytical Study. Palestine: Al-quds University.

Vallaryes, F., Del laCruz, C., \& Sasia, P. (2009). University Social Responsibility. Mexico: McGraw Hill.

Vasilescua, R., Barnab, C., Epurec, M., \& Baicud, C. (2010). Developing university social responsibility: A model for the challenges of the new civil society. Procedia Social and Behavioral Sciences, 2(2), 4177-4182. https://doi.org/10.1016/j.sbspro.2010.03.660

\section{Copyrights}

Copyright for this article is retained by the author(s), with first publication rights granted to the journal.

This is an open-access article distributed under the terms and conditions of the Creative Commons Attribution license (http://creativecommons.org/licenses/by/4.0/). 